\title{
Impact of use of gastric-acid suppressants and oral anticancer agents on survival outcomes: a systematic review and meta-analysis
}

\section{Gastric acid suppressants versus no gastric acid suppressants}

\author{
Alice Indini 1, Fausto Petrelli 2, Gianluca Tomasello 3, Erika Rijavec 1, Antonio Facciorusso 4 , \\ Francesco Grossi ${ }^{1}$ and Michele Ghidini ${ }^{1, *}$ \\ 1 Oncology Unit, Fondazione IRCCS Ca' Granda Ospedale Maggiore Policlinico, Milano, Italy \\ 2 Oncology Unit, ASST Bergamo Ovest, Treviglio (BG), Italy \\ 3 Oncology Unit, Niguarda Cancer Center, Grande Ospedale Metropolitano Niguarda, Milan, Italy \\ 4 Gastroenterology Unit, Università Degli Studi di Foggia, Italy \\ * Correspondence: Michele.ghidini@policlinico.mi.it; Tel.: 02.5503.2660; Fax.: 02.5503.2659
}

\begin{abstract}
We performed a systematic review and meta-analysis to evaluate the role of gastric acid suppressant use on outcomes of tyrosine kinase inhibitors (TKIs) and oral chemotherapy. We identified all researches evaluating the effect of GAS use on patients receiving oral chemotherapy or TKIs for solid tumors. The pooled hazard ratios (HRs) and 95\% confidence interval (95\% CI) for overall survival (OS) and progression-free survival (PFS) were calculated with fixed-effects or random-effects model. The study population included $n=16$ retrospective studies and 372,418 patients. Series concerned gastrointestinal tract tumors ( $\mathrm{n}=5$ studies), renal cell carcinomas (RCC, $\mathrm{n}=3$ studies), non-small cell lung cancers (NSCLC, $\mathrm{n}=5$ studies), and soft tissue sarcomas or mixed histologies solid tumors in $n=3$ studies. The pooled HRs for OS and PFS were 1.31 (95\% CI: 1.20 1.43; $\mathrm{P}<01)$ and $1.3(95 \% \mathrm{CI} 1.07-1.57 ; \mathrm{P}<0.01)$ for GAS and no GAS users, respectively. Only studies of EGFR mutated NSCLC patients receiving TKIs and those with colorectal cancer receiving oral chemotherapy showed a significant correlation between GAS and poor survival. Our study supports the evidence of a possible negative impact of concomitant GAS therapy on survival outcomes of patients receiving oral anti-cancer drugs.
\end{abstract}

Keywords: gastric acid suppressant; chemotherapy; tyrosine kinase inhibitors; proton pump inhibitors

\section{Introduction}

Oral chemotherapy has historically been part of therapeutic regimens for the treatment of cancer [1-3]. Over the last years, new oral anti-cancer agents acting as multi-tyrosine kinase inhibitors (TKIs) has dramatically changed prognosis and thereby became standard treatment for several types of tumors [4-9]. TKIs targeting the epidermal growth factor receptor (EGFR) (e.g. gefitinib, erlotinib, afatinib, osimertinib) are currently approved for treatment of EGFR mutant non-small cell lung carcinoma (NSCLC), and multi-targeted TKIs (e.g. sunitinib, axitinib, sorafenib, pazopanib) for the treatment of renal cell carcinoma (RCC). Moreover, plenty of new TKIs are currently being tested in clinical trials in several types of solid tumors. The use of oral drugs has a positive impact on patients' quality of life for the convenience of self-administration; however, there is a significant risk of drug-drug interactions. The diffusion of these drugs often parallels that of 
gastric acid suppressants (GAS), such as proton pump inhibitors (PPI) or histamine-2 receptor antagonists (H2RA), GAS commonly represent part of the complex drug regimen of an average oncologic patient, with an estimated rate of 50\% inappropriate PPIs prescriptions, both in hospital and ambulatory settings [10]. Because of the oral administration and $\mathrm{pH}$-dependent solubility of chemotherapy and TKIs, concerns have been raised on the possible effect of co-administering drugs which raise gastric $\mathrm{pH}][11,12]$. Chronic acid suppression can reduce the effectiveness of drugs that require an acidic $\mathrm{pH}$ for their absorption [13]. Retrospective data suggest that TKIs plasma concentration is decreased in patients receiving concomitant GAS therapy with subsequent poorer oncologic outcomes $[14,15]$, however pooled analyses of patients enrolled in clinical trials have shown inconsistent results $[16,17]$.

The aim of our meta-analysis is to define whether concomitant use of GAS therapy (either PPI or H2RA) in patients receiving treatment with oral anti-cancer agents (i.e. chemotherapy or TKIs) is associated with survival outcomes.

\section{Results}

A total of 353 potentially eligible records were identified in the electronic databases. After exclusion of $\mathrm{n}=337$ not pertinent papers, $\mathrm{n}=16$ were selected for inclusion in quantitative analysis ( $n=372,418$ patients included, with $12 \%$ of patients receiving concomitant GAS therapy) [16-31]. The search results and characteristics of the included studies are presented in figure 1 and tables 1-2.
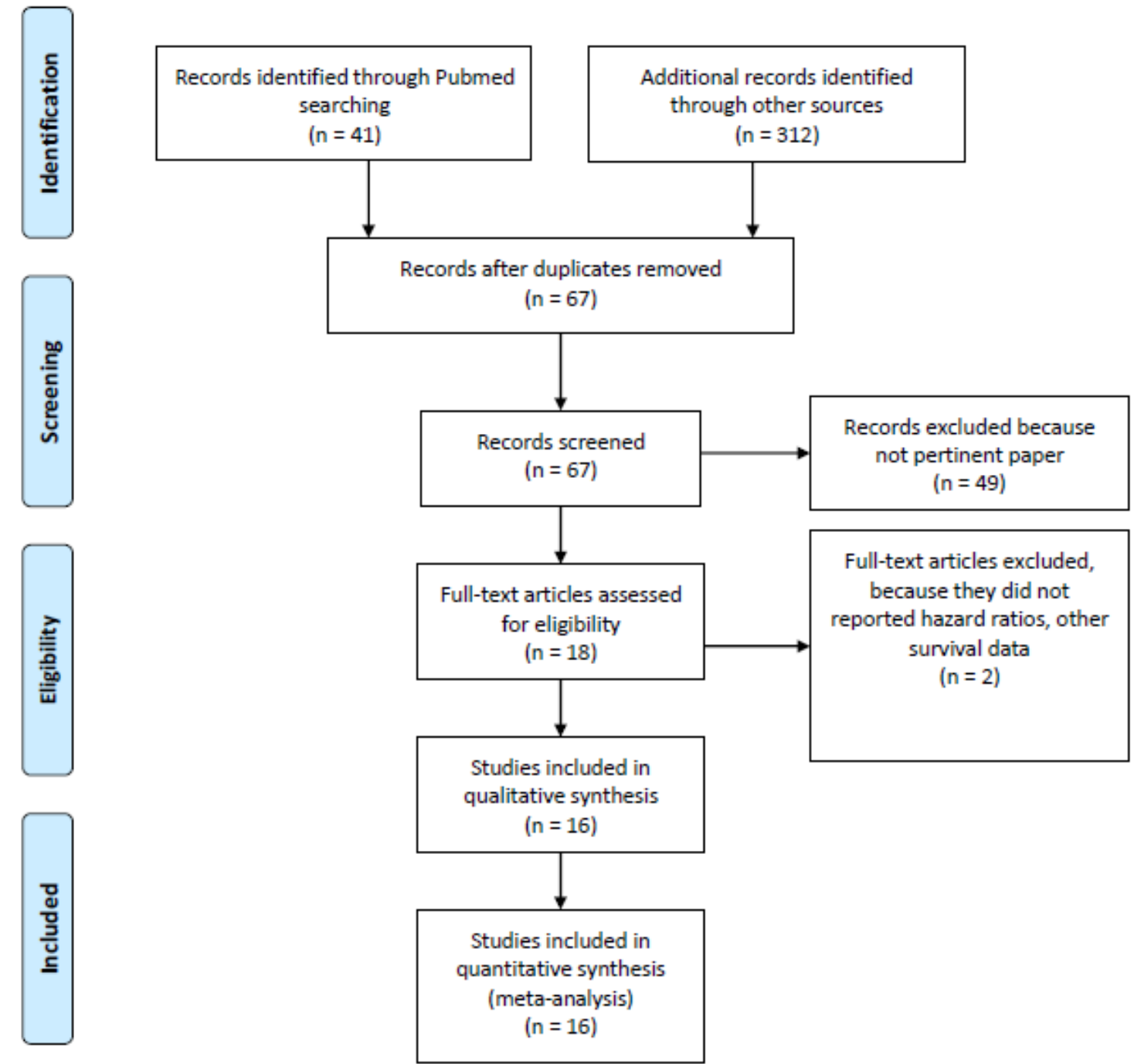

Figure 1. Flow diagram of included studies. 
Table 1. Main characteristics of the included studies.

\begin{tabular}{|c|c|c|c|c|c|c|c|}
\hline Author & Principal institution(s) involved & Study design & $\begin{array}{l}\text { Study } \\
\text { period }\end{array}$ & $\begin{array}{l}\text { Number of } \\
\text { patients }\end{array}$ & $\begin{array}{l}\text { Patients' disease } \\
\text { characteristic }\end{array}$ & $\begin{array}{c}\text { Oral } \\
\text { Anticancer } \\
\text { drug }\end{array}$ & $\begin{array}{l}\text { Type of } \\
\text { GAS }\end{array}$ \\
\hline На, 2014 & $\begin{array}{l}\text { Cross Cancer Institute, Department of Oncology, } \\
\text { Edmonton, Alberta, Canada }\end{array}$ & retrospective & 2006-2013 & 383 & $\mathrm{mRCC}$ & Sunitinib & PPI \\
\hline Sun, 2016 & $\begin{array}{c}\text { Cross Cancer Institute, Department of Oncology, } \\
\text { Edmonton, Alberta, Canada }\end{array}$ & retrospective & 2008-2012 & 298 & Early stage CRC & Capecitabine & PPI \\
\hline Chu, 2015 & $\begin{array}{l}\text { Cross Cancer Institute, Department of Oncology, } \\
\text { Edmonton, Alberta, Canada }\end{array}$ & retrospective & 2007-2012 & 507 & $\begin{array}{c}\text { EGFR mutant } \\
\text { advanced NSCLC }\end{array}$ & Erlotinib & $\begin{array}{c}\text { PPI, } \\
\text { H2RA }\end{array}$ \\
\hline Zenke, 2016 & $\begin{array}{l}\text { Department of Thoracic Oncology, National } \\
\text { Cancer Center Hospital East, Kashiwa, Japan }\end{array}$ & retrospective & 2008-2011 & 130 & $\begin{array}{c}\text { EGFR mutant } \\
\text { advanced NSCLC }\end{array}$ & $\begin{array}{l}\text { Gefitinib } \\
\text { Erlotinib }\end{array}$ & $\begin{array}{c}\text { PPI, } \\
\text { H2RA } \\
\end{array}$ \\
\hline $\begin{array}{l}\text { Kumarakulasinghe, } \\
2016 \\
\end{array}$ & $\begin{array}{c}\text { Department of Haematology-Oncology, National } \\
\text { University Cancer Institute, Singapore }\end{array}$ & retrospective & 2008-2013 & 157 & $\begin{array}{c}\text { EGFR mutant } \\
\text { advanced NSCLC }\end{array}$ & $\begin{array}{l}\text { Gefitinib } \\
\text { Erlotinib }\end{array}$ & $\begin{array}{c}\text { PPI, } \\
\text { H2RA }\end{array}$ \\
\hline Chen, 2016 & $\begin{array}{l}\text { Chang Gung Memorial Hospital-Kaohsiung } \\
\text { Medical Center, Chang Gung University College } \\
\text { of Medicine, Kaohsiung, Taiwan }\end{array}$ & retrospective & 2010-2013 & 269 & $\begin{array}{c}\text { EGFR mutant } \\
\text { advanced NSCLC }\end{array}$ & $\begin{array}{l}\text { EGFR TKIs } \\
\text { NOS }\end{array}$ & PPI \\
\hline Graham, 2016 & $\begin{array}{c}\text { Department of Oncology, Cancer Centre of } \\
\text { Southeastern Ontario, Queen's University, } \\
\text { Kingston }\end{array}$ & retrospective & $2005-2011$ & 117 & CRC & NA & PPI \\
\hline Chu, 2017 & $\begin{array}{l}\text { Cross Cancer Institute, Department of Oncology, } \\
\text { Edmonton, Alberta, Canada }\end{array}$ & $\begin{array}{c}\text { retrospective } \\
\text { analysis (phase III } \\
\text { trial) } \\
\end{array}$ & $2008-2012$ & 545 & GEJC & Capecitabine & PPI \\
\hline Zhang, 2017 & $\begin{array}{l}\text { Guangdong Medical University Affiliated } \\
\text { Longhua Central Hospital, Shenzhen, China }\end{array}$ & retrospective & 2008-2016 & 125 & CRC & Capecitabine & PPI \\
\hline Lalani, 2017 & $\begin{array}{l}\text { Department of Medical Oncology, Dana-Farber } \\
\text { Cancer Institute, Boston, USA }\end{array}$ & $\begin{array}{l}\text { pooled analysis } \\
\text { (phase II/III } \\
\text { studies) }\end{array}$ & 2003-2013 & 2188 & mRCC & $\begin{array}{l}\text { Sunitinib } \\
\text { Axitinib } \\
\text { Sorafenib } \\
\end{array}$ & PPI \\
\hline McAlister, 2018 & $\begin{array}{c}\text { Vanderbilt-Ingram Cancer Center, Nashville, } \\
\text { USA }\end{array}$ & retrospective & 2010-2015 & 90 & $\mathrm{mRCC}$ & Pazopanib & $\begin{array}{c}\text { PPI, } \\
\text { H2RA } \\
\end{array}$ \\
\hline Tvingsholm, 2018 & $\begin{array}{c}\text { Danish Cancer Society Research Center, } \\
\text { Copenhagen, Denmark (Danish Cancer Registry) }\end{array}$ & retrospective & $1995-2011$ & 353071 & $\begin{array}{l}\text { Solid Tumors } \\
\text { (Danish Cancer } \\
\text { Registry) }\end{array}$ & NA & PPI \\
\hline Wong, 2019 & $\begin{array}{l}\text { Cross Cancer Institute, Department of Oncology, } \\
\text { Edmonton, Alberta, Canada }\end{array}$ & retrospective & 2004-2013 & 389 & stage II-III CRC & Capecitabine & PPI \\
\hline Fang, 2019 & $\begin{array}{c}\text { Chang Gung Memorial Hospital, Chiayi Branch, } \\
\text { Puzi City, Chiayi County, Taiwan } \\
\end{array}$ & retrospective & $1997-2013$ & 1278 & $\begin{array}{c}\text { EGFR mutant } \\
\text { advanced NSCLC }\end{array}$ & Gefitinib & PPI \\
\hline
\end{tabular}




\begin{tabular}{|c|c|c|c|c|c|c|c|}
\hline Mir, 2019 & $\begin{array}{c}\text { Gustave Roussy, Sarcoma Group, Villejuif, } \\
\text { France }\end{array}$ & retrospective & $\begin{array}{l}2005-2007 \\
2008-2010\end{array}$ & 333 & STS & Pazopanib & $\begin{array}{c}\text { PPI, } \\
\text { H2RA }\end{array}$ \\
\hline Sharma, 2019 & $\begin{array}{l}\text { The University of Mississippi, Oxford, } \\
\text { Mississippi, USA (SEER Database) }\end{array}$ & retrospective & 2007-2012 & 12538 & $\begin{array}{c}\text { Solid Tumors } \\
\text { (SEER Database) }\end{array}$ & TKIs & PPI \\
\hline
\end{tabular}

Legend: CRC, colorectal cancer; GEJC, gastro-esophageal junction cancer; EGFR, epidermal growth factor receptor; GAS, gastric acid suppressants; H2RA, histamine-2 receptor antagonists; NA, not applicable; NOS, not otherwise specified; NSCLC, non-small cell lung cancer; PPI, proton-pump inhibitors; mRCC, metastatic renal cell carcinoma; SEER, Surveillance, Epidemiology, and End Results; STS, soft-tissue sarcoma; TKI, tyrosine kinase inhibitors; USA, United States of America.

Table 2. Response and survival outcomes in the analyzed studies.

\begin{tabular}{|c|c|c|c|c|c|c|c|c|}
\hline Authors, year & $\begin{array}{l}\text { Median follow } \\
\text { up, months }\end{array}$ & $\begin{array}{c}\text { Criteria for overlapping between } \\
\text { GAS and anticancer treatment } \\
\text { (time overlapping \%) }\end{array}$ & $\begin{array}{c}\text { Therapeutic } \\
\text { approach, n (\%) }\end{array}$ & ORR & $\begin{array}{c}\text { OS HR } \\
(95 \% \mathrm{CI})^{*}\end{array}$ & $\begin{array}{l}\text { PFS HR } \\
(95 \% \mathrm{CI})^{*}\end{array}$ & $\begin{array}{l}\text { Type of } \\
\text { analysis }\end{array}$ & $\begin{array}{l}\text { Quality } \\
\text { NOS score }\end{array}$ \\
\hline \multirow{2}{*}{ На, 2014} & \multirow{2}{*}{ NA } & & GAS: $45(20 \%)$ & NA & \multirow{2}{*}{$\begin{array}{c}1.43 \\
(0.95-2.15)\end{array}$} & \multirow{2}{*}{$\begin{array}{c}1.36 \\
(0.92-2.01)\end{array}$} & \multirow{2}{*}{ UVA } & \multirow{2}{*}{5} \\
\hline & & 100 & No GAS: $186(80 \%)$ & NA & & & & \\
\hline \multirow{2}{*}{ Sun, 2015} & \multirow{2}{*}{ NA } & & GAS: $77(26 \%)$ & NA & \multirow{2}{*}{$\begin{array}{c}0.94 \\
(0.49-1.78)\end{array}$} & \multirow{2}{*}{$\begin{array}{c}0.61 \\
(0.34-1.08)\end{array}$} & \multirow{2}{*}{ MVA } & \multirow{2}{*}{5} \\
\hline & & Any PPI prescription & No GAS: $202(74 \%)$ & NA & & & & \\
\hline \multirow{2}{*}{ Chu, 2015} & \multirow{2}{*}{ NA } & & GAS: $124(25 \%)$ & $5.6 \%$ & \multirow{2}{*}{$\begin{array}{c}1.37 \\
(1.11-1.69)\end{array}$} & \multirow{2}{*}{$\begin{array}{c}1.83 \\
(1.48-2.25)\end{array}$} & \multirow{2}{*}{ MVA } & \multirow{2}{*}{6} \\
\hline & & $\geq 20$ & No GAS: 383 (75\%) & $18.5 \%$ & & & & \\
\hline \multirow[b]{2}{*}{ Zenke, 2016} & \multirow{2}{*}{$36(10.1-85.2)$} & & GAS: $47(36 \%)$ & $64 \%$ & \multirow[b]{2}{*}{$\begin{array}{c}1.41 \\
(0.83-2.35)\end{array}$} & \multirow[b]{2}{*}{$\begin{array}{c}1.15 \\
(0.73-1.79)\end{array}$} & \multirow[b]{2}{*}{ MVA } & \multirow[b]{2}{*}{7} \\
\hline & & $\begin{array}{l}\text { PPI/H2RA sequentially or } \\
\text { concurrently to anti-EGFR }\end{array}$ & No GAS: 83 (64\%) & $63 \%$ & & & & \\
\hline \multirow{2}{*}{$\begin{array}{l}\text { Kumarakulasinghe, } \\
2016 \\
\end{array}$} & \multirow{2}{*}{50} & & GAS: $55(35 \%)$ & NA & \multirow{2}{*}{$\begin{array}{c}1.37 \\
(0.89-2.12) \\
\end{array}$} & \multirow{2}{*}{$\begin{array}{c}1.47 \\
(0.92-2.35) \\
\end{array}$} & \multirow{2}{*}{ MVA } & \multirow{2}{*}{7} \\
\hline & & $\geq 30$ & No GAS: $102(65 \%)$ & NA & & & & \\
\hline \multirow{2}{*}{ Chen, 2016} & \multirow{2}{*}{24.5} & & GAS: $57(21 \%)$ & NA & \multirow{2}{*}{$\begin{array}{c}2.27 \\
(1.26-4.11)\end{array}$} & \multirow{2}{*}{$\begin{array}{c}2.00 \\
(0.96-4.17) \\
\end{array}$} & & \\
\hline & & $\geq 30$ & No GAS: 212 (79\%) & NA & & & MVA & 6 \\
\hline & & & GAS: $117(9 \%)$ & NA & & & & \\
\hline Graham, 2016 & NA & NA & $\begin{array}{c}\text { No GAS: } 1187 \\
(91 \%)\end{array}$ & NA & $\begin{array}{c}1.34 \\
(1.01-1.79)\end{array}$ & NA & MVA & 7 \\
\hline & NA & & GAS: $119(44 \%)$ & $36 \%$ & 1.41 & 1.68 & MVA & 5 \\
\hline Chu, 2017 & NA & $\geq 20$ & No GAS: $155(56 \%)$ & $42 \%$ & $(1.11-1.71)$ & $(1.42-1.94)$ & MVA & 5 \\
\hline & 66 & & GAS: $29(23 \%)$ & $52.2 \%$ & 0.30 & 0.37 & UVA* $^{*}$ & \\
\hline Zhang, 2017 & 66 & $\geq 200 \mathrm{mg}$ PPI & No GAS: 96 (77\%) & $36.5 \%$ & $(0.09-0.99)$ & $(0.11-1.23)^{*}$ & MVA & 7 \\
\hline I alani 2017 & NA & & GAS: $120(5 \%)$ & $23.3 \%$ & 1.05 & 1.02 & & \\
\hline Lalanı, 2017 & NA & $\geq 1$ dose PPI & No GAS: & $27.4 \%$ & $(0.77-1.44)$ & $(0.79-1.30)$ & MVA & 5 \\
\hline
\end{tabular}




\begin{tabular}{|c|c|c|c|c|c|c|c|c|}
\hline & & & $2068(95 \%)$ & & & & & \\
\hline \multirow{2}{*}{ McAlister, 2018} & \multirow{2}{*}{ NA } & & GAS: $66(73 \%)$ & NA & \multirow{2}{*}{$\begin{array}{c}0.99 \\
(0.51-1.93)\end{array}$} & \multirow{2}{*}{$\begin{array}{c}1.25 \\
(0.76-2.07)\end{array}$} & \multirow{2}{*}{ MVA } & \multirow{2}{*}{5} \\
\hline & & $\geq 90$ days & No GAS: 24 (27\%) & NA & & & & \\
\hline \multirow[b]{2}{*}{ Tvingsholm, 2018} & \multirow[b]{2}{*}{$1.52(0.50-3.89)$} & & GAS: $41218(11.7 \%)$ & NA & \multirow[b]{2}{*}{$\begin{array}{c}1.29 \\
(1.27-1.31)\end{array}$} & \multirow[b]{2}{*}{ NA } & \multirow[b]{2}{*}{ MVA } & \multirow[b]{2}{*}{7} \\
\hline & & $\geq 2$ prescriptions within 6 months & $\begin{array}{c}\text { No GAS: } 311853 \\
(88.3 \%)\end{array}$ & NA & & & & \\
\hline \multirow[b]{2}{*}{ Wong, 2018} & \multirow[b]{2}{*}{ NA } & & GAS: $50(23.4 \%)$ & NA & \multirow{2}{*}{$\begin{array}{c}1.68 \\
(0.75-3.80)\end{array}$} & \multirow{2}{*}{$\begin{array}{c}2.20 \\
(1.14-4.25)\end{array}$} & \multirow[b]{2}{*}{ MVA } & \multirow[b]{2}{*}{5} \\
\hline & & Any time PPI during capecitabine & $\begin{array}{c}\text { No GAS: } 164 \\
(76.6 \%)\end{array}$ & NA & & & & \\
\hline \multirow{2}{*}{ Fang, 2019} & \multirow{2}{*}{ NA } & & GAS: $309(24 \%)$ & NA & \multirow{2}{*}{$\begin{array}{c}1.67 \\
(1.33-2.09)\end{array}$} & \multirow{2}{*}{$\begin{array}{c}0.99 \\
(0.80-1.23) \\
\end{array}$} & \multirow{2}{*}{ MVA } & \multirow{2}{*}{7} \\
\hline & & $\geq 20 \%$ & No GAS: 969 (76\%) & NA & & & & \\
\hline \multirow{2}{*}{ Mir, 2019} & \multirow{2}{*}{$27.6(22.9-35.4)$} & & GAS: $59(18 \%)$ & NA & \multirow{2}{*}{$\begin{array}{c}1.81 \\
(1.31-2.49)\end{array}$} & \multirow{2}{*}{$\begin{array}{c}1.49 \\
(1.11-1.99)\end{array}$} & \multirow{2}{*}{ MVA } & \multirow{2}{*}{6} \\
\hline & & $\geq 80$ & No GAS: $273(82 \%)$ & NA & & & & \\
\hline \multirow[b]{2}{*}{ Sharma, 2019} & \multirow[b]{2}{*}{ NA } & & GAS: $2843(22.7 \%)$ & NA & \multirow{2}{*}{$\begin{array}{c}1.10 \\
(1.04-1.17)\end{array}$} & \multirow[b]{2}{*}{ NA } & \multirow[b]{2}{*}{ MVA } & \multirow[b]{2}{*}{8} \\
\hline & & $\geq 30$ days within 3 months & $\begin{array}{c}\text { No GAS: } 9695 \\
(77.3 \%)\end{array}$ & NA & & & & \\
\hline
\end{tabular}

* when both uni and multivariate analyses were performed, HR results of multivariate analyses are reported. Legend: CI, confidence interval; GAS, gastric acid suppressants; HR, hazard ratio; NA, not available; NA, not determined; NOS, Newcastle-Ottawa Scale; MVA, multivariate analysis; ORR, overall response rate; OS, overall survival; PFS, progression free survival; UVA, univariate analysis. 
All studies were retrospective except for a pooled analysis of phase 2-3 studies by Lalani et al. and a secondary analysis of a randomized prospective trial by $\mathrm{Chu}$ et al. Oncologic treatment consisted in oral TKIs in $n=11$ studies, while in $n=4$ studies patients received oral chemotherapy (i.e. capecitabine); one study did not include information regarding the type of study drugs. Oncologic diagnoses were cancers of the gastrointestinal tract (GI, $n=5$ studies), RCC ( $n=3$ studies), NSCLC ( $n=5$ studies), and soft tissue sarcomas or mixed histologies solid tumors in $\mathrm{n}=3$ studies. Quality according to NOS scale was moderate (range 5-8; median 6).

\subsection{Overall survival and progression-free survival with GAS vs no GAS}

$\mathrm{N}=15$ studies reported data on OS. Because the heterogeneity test showed a high level of heterogeneity $\left(\mathrm{I}^{2}=68 \%, \mathrm{P}<0.01\right)$ among studies, a random-effects model was used for the analysis. OS of patients receiving concomitant GAS therapy was significantly worse (HR =1.31, 95\% CI: 1.20-1.43; $\mathrm{P}<01$; Figure 2) compared to those of patients not receiving GAS. Similarly, the use of GAS reduced PFS in $\mathrm{n}=13$ studies (HR=1.3, 95\%CI 1.07-1.57; $\mathrm{P}<0.007$; Figure 3), which reported data on PFS. Heterogeneity was high $\left(\mathrm{I}^{2}=74 \%\right)$, so a random effect model was used.

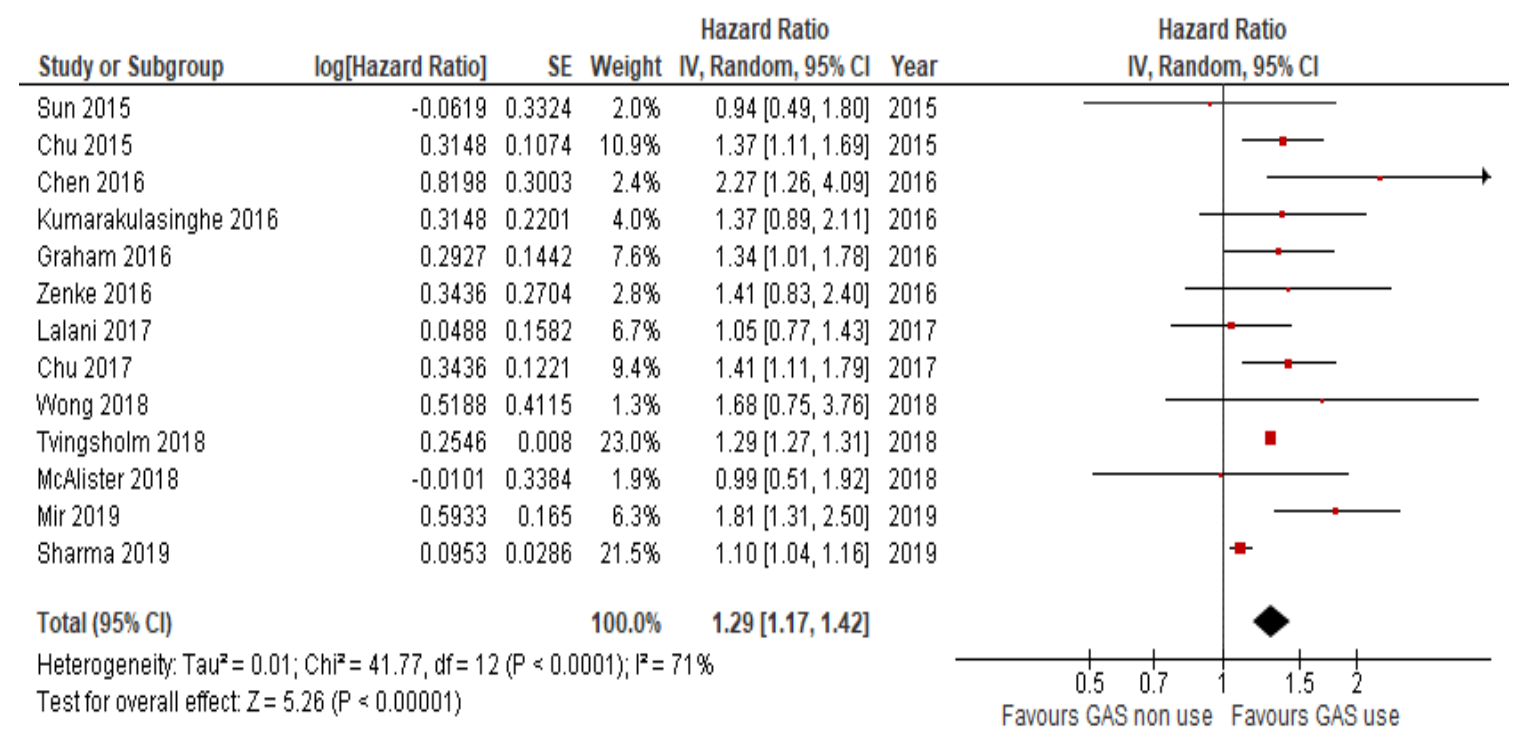

Figure 2. Forest plot for overall survival of the analyzed studies.

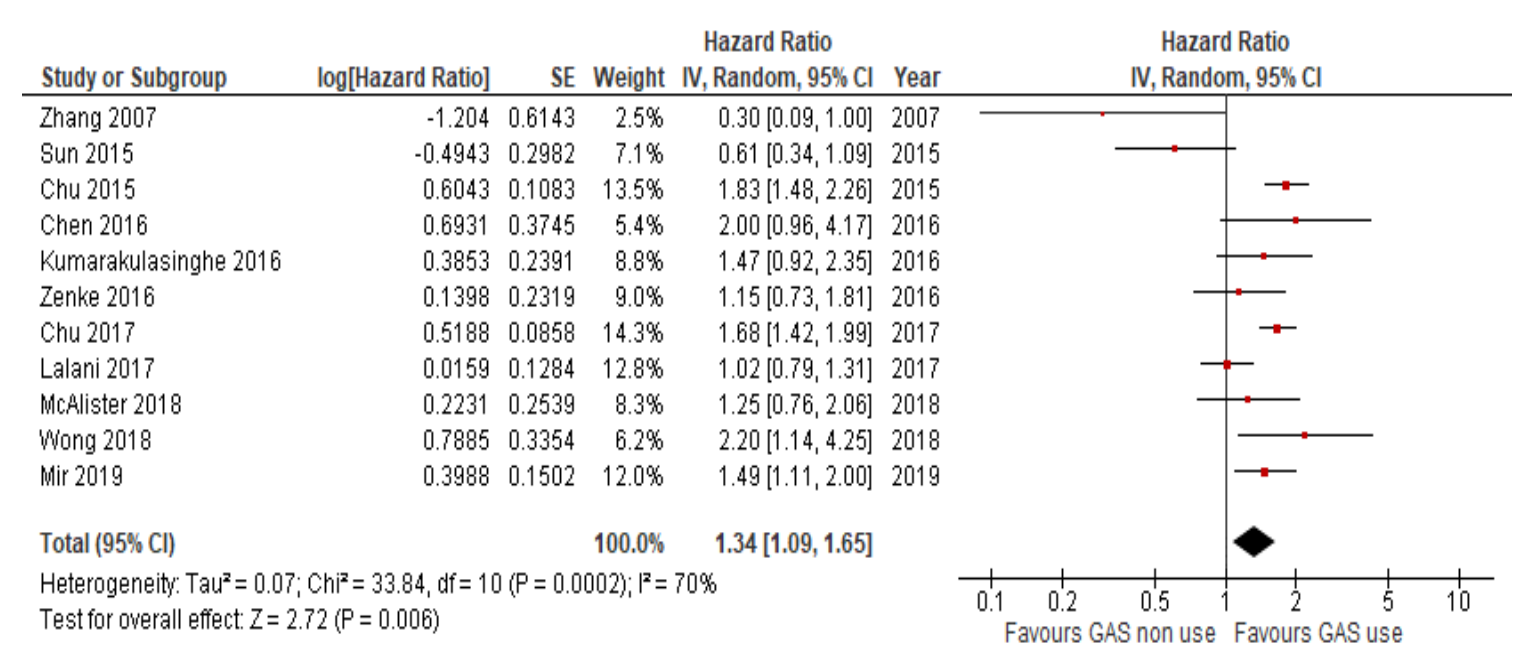

Figure 3. Forest plot for progression free survival of the analyzed studies. 
In a separate analysis of studies involving patients treated with TKIs, the use of concomitant GAS was similarly associated to poorer OS (HR=1.35, 95\%CI 1.16-1.56; P<0.01). Similarly, capecitabine assumption with GAS resulted in increased mortality ( $\mathrm{HR}=1.37,95 \% \mathrm{CI} 1.1-1.7 ; \mathrm{P}<0.01)$. We also searched for a distinct correlation of concomitant GAS in different tumor types: only studies of EGFR mutated NSCLC patients receiving TKIs and either PPIs or H2RAs and those with GI cancers receiving all PPIs and oral chemotherapy retained a significant correlation between GAS and poor survival (HR=1.47, 95\%CI 1.27-1.71; $\mathrm{P}<.01$ and $\mathrm{HR}=1.3,95 \% \mathrm{CI} 1.02-1.66 ; \mathrm{P}=0.04)$, while in case of renal cell carcinoma the correlation between GAS assumption and reduced survival was missing. In patients with lung cancer on anti-EGFR, regression between H2RA and HR for OS was not significant, so the contribution of H2RA does not seem relevant for the final outcome.

In some studies, both PPIs and H2RAs were administered. After exclusion of these studies, $\mathrm{n}=7$ publications included only patients taking PPIs and HR for OS was similar to the whole population $(\mathrm{HR}=1.22$, 95\%CI 1.09-1.36; $\mathrm{P}<.01)$. In studies that reported median follow up ( $\mathrm{n}=6)$, OS was still poorer in patients taking GAS $(\mathrm{HR}=1.29,95 \% \mathrm{CI} 1.27-1.31 ; \mathrm{P}<0.01)$.

\subsection{Overall response rate}

In few studies with data available, PPIs did not influence ORR (OR=0.89, 95\%CI 0.53-1.47; $\mathrm{P}=0.64$, figure 4$)$.

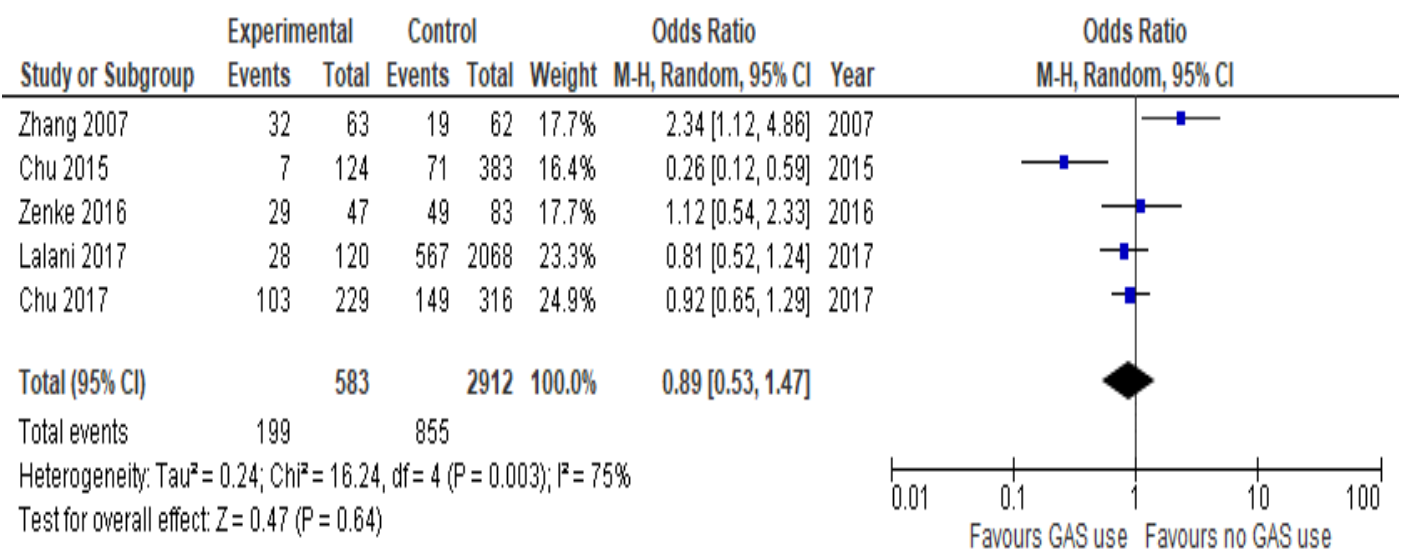

Figure 4. Forest plot for overall response rate of the analyzed studies.

\subsection{Publication bias}

A funnel plot was used to assess publication bias in the studies evaluating OS with concomitant GAS versus no GAS therapy in cancer patients. No publication bias was detected. Also Egger's test was not significant $(\mathrm{P}=0.39)$ (Figure 5). 


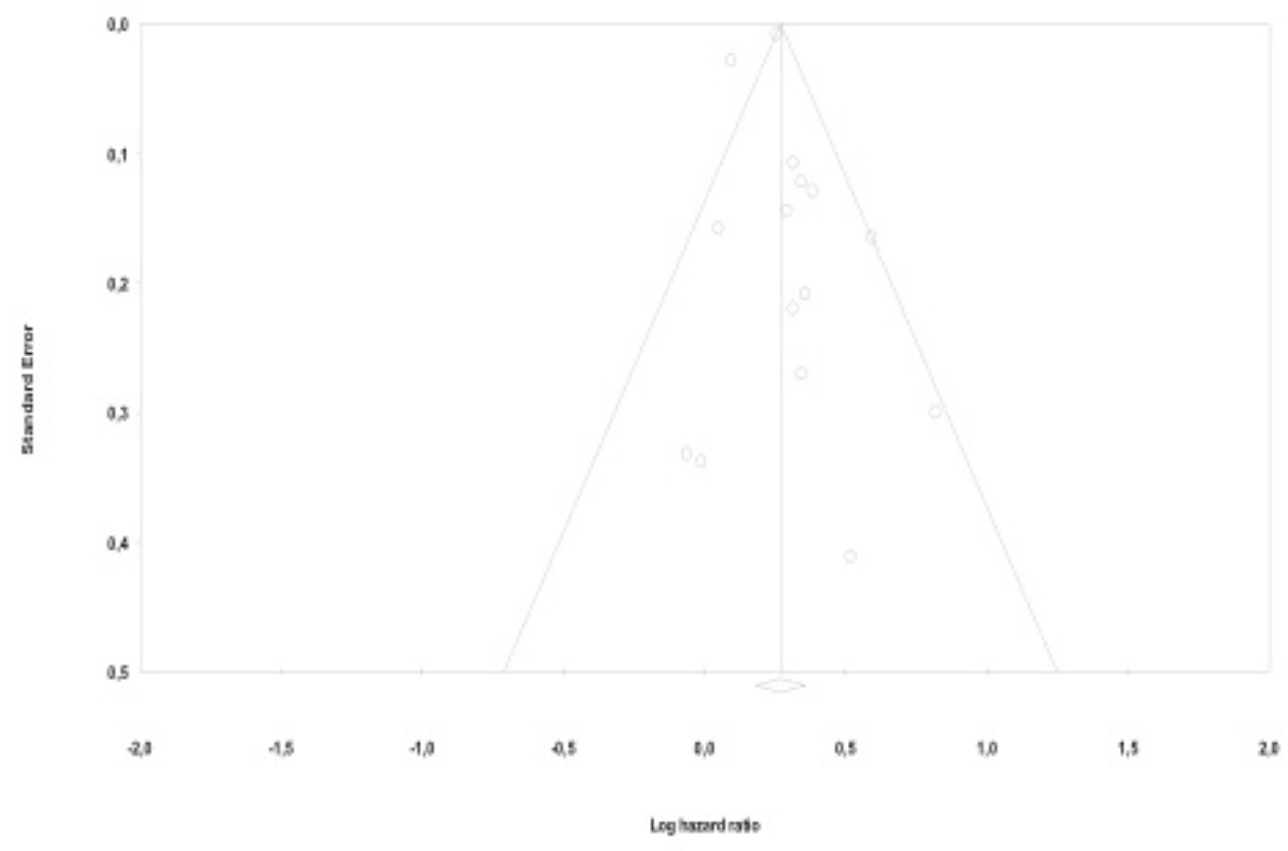

Figure 5. Funnel plot for publication bias in overall survival analysis.

\section{Discussion}

This is the first meta-analysis exploring the role of concomitant GAS therapy during oral anti-cancer agents for treatment of solid tumors. According to our results, GAS therapy seems to negatively impact on OS and PFS, while it has no impact on ORR.

GAS, and above all PPIs are among the most commonly prescribed drugs worldwide. Their principal application is treatment of gastroesophageal inflammatory syndromes, such as gastroesophageal reflux disease, esophagitis, and peptic ulcer disease [32]. Given to their mild toxicity profile, the use of PPIs has spread over the last 20 years, and we are now facing an overuse in patients with benign conditions or not needing this specific therapy. Recently, various studies have related PPIs use to increased incidence of respiratory tract and Clostridium difficile infections, mainly related to an altered commensal intestinal microbiome, as a consequence of raised gastric $\mathrm{pH}$ and bacterial overgrowth [33].

The clinical impact of concomitant use of GAS therapy and oral anti-cancer agents remains controversial. Numerous pharmacokinetic studies have addressed this question, showing a possible detrimental effect of GAS on oral anti-cancer drugs' absorption. However, this phenomenon varies according not only to the drugs analyzed, but depends also on specific drug-drug interactions differing among drugs of the same class [11,12,34,35]. As an example, Egorin et al. showed that PPIs may significantly decrease dasatinib plasmatic levels, while they do not impact on imatinib levels [34]. A similar effect was shown in a small series of patients using concomitant GAS and erlotinib [11], but was not confirmed by data of patients included in the BR.21 trial database [35]. This retrospective analysis on clinical outcomes of patients receiving concomitant GAS and erlotinib showed no differences in plasma drug levels and survival outcomes compared with patients who did not take concomitant GAS [35]. However, the pH-dependent absorption of erlotinib was confirmed in a randomized pharmacokinetic study, which demonstrated that concomitant Cola intake led to a clinically relevant increase in erlotinib bioavailability during esomeprazole treatment due to a temporarily lowered intragastric $\mathrm{pH}$ [36]. Analyses on the pharmacokinetics of different TKIs showed that afatinib is highly soluble throughout the physiologic $\mathrm{pH}$ range and may therefore have fewer interactions with GAS, compared with gefitinib or erlotinib [37]. A similar effect was observed for osimertinib, which plasmatic levels were not determined by food or PPIs co-administration [12]. With our meta-analysis, we reported a significant correlation between GAS and poor survival only for the NSCLC and CRC subgroups, while there was no significant impact on 
survival when RCC series were considered. A possible explanation may be found in the difference between oral TKIs used in NSCLCs and RCCs. Indeed, TKIs used in lung cancer own anti-EGFR activity (gefitinib and erlotinib), while TKIs used in RCCs have mainly anti- vascular endothelial growth factor (VEGF) properties (sunitinib, sorafenib, axitinib and pazopanib). Moreover, our results are consistent with findings of a previous pooled analysis of metastatic RCC patients treated in phase II and III trials. Indeed, OS results were similar between PPIs and non-PPIs users in case of anti-VEGF TKIs use [16].

Two are the main concerns related to alterations in pharmacokinetics during concomitant GAS therapy. The first is that combined use of PPIs and TKIs may increase the treatment-related adverse events (AEs) of both drugs. Although intuitive, also this mechanism is controversial: in a recent report from Cho et al., concomitant GAS therapy increased gefitinib-induced hepatotoxicity [38]. However, another case series of patients treated with gefitinib and erlotinib did not show differences in the incidence of cutaneous AEs and diarrhea, when comparing patients receiving concomitant GAS to those who did not [30]. Similar reports of patients undergoing concomitant capecitabine and PPIs showed that rates of treatment discontinuation and/or dose reduction due to toxicities was comparable to that of patients not receiving GAS therapy [20,29].

The second important issue lies in the potential reduced absorption and subsequent compromised anti-cancer drug effect. Reports from the Literature on this topic mainly consist of case series, reporting heterogeneous data in terms of patients' populations, anti-cancer drugs (chemotherapy, TKIs), GAS therapy (PPIs, H2RA, or both), and outcomes (survival vs response vs AEs incidence). Our meta-analysis confirmed that concomitant GAS can have a negative impact on PFS and OS, however without significant effects on ORR. One of the possible reasons for the worse survival outcomes is that patients requiring GAS are older and have various comorbidities (e.g. cardiovascular disease requiring aspirin and therefore PPIs therapy). Another theory is that concomitant GAS therapy reduces serum levels of anti-cancer drugs under the therapeutic threshold, thus increasing the risk for distant metastasis and disease progression. Although previous studies show that TKIs are effective even at low serum levels, it is recognized that the cerebrospinal fluid penetration rate of first-generation TKIs is only around 2\% [39]. Thus, the concomitant use of drugs reducing gastric absorption of TKIs may further reduce their serum levels to an insufficient plasmatic concentration [40].

Our meta-analysis has some intrinsic limitations. First of all, patients taking PPIs may have an intrinsic poor performance status and/or chronic conditions that require continuous GAS. Secondly, use of PPIs was not offered with a randomized design so that patients treated with PPIs may have suffered from concomitant gastritis/dyspepsia and/or may have taken steroids for supportive care, consequently needing chronic GAS therapy. Thirdly, there is uncertainty regarding the correct administration of PPIs straightly before the antitumoral treatment. Finally, other pharmacological interactions (e.g. with the CYP3A4 citocrome) may have reduced plasmatic concentration of anti-EGFR agents.

\section{Materials and Methods}

This study followed the Meta-analysis Of Observational Studies in Epidemiology (MOOSE) group guidelines and checklist [41] (Fig. 1, Tab. 3). 
Table 3. MOOSE Checklist for Meta-analyses of Observational Studies.

\begin{tabular}{|c|c|c|}
\hline $\begin{array}{l}\text { Item } \\
\text { No }\end{array}$ & Recommendation & $\begin{array}{l}\text { Reported on } \\
\text { Page No }\end{array}$ \\
\hline \multicolumn{3}{|c|}{ Reporting of background should include } \\
\hline 1 & Problem definition & 1,2 \\
\hline 2 & Hypothesis statement & 1,2 \\
\hline 3 & Description of study outcome(s) & 11 \\
\hline 4 & Type of exposure or intervention used & 11 \\
\hline 5 & Type of study designs used & 11 \\
\hline 6 & Study population & 11 \\
\hline \multicolumn{3}{|c|}{ Reporting of search strategy should include } \\
\hline 7 & Qualifications of searchers (eg, librarians and investigators) & 1 \\
\hline 8 & Search strategy, including time period included in the synthesis and key words & 11 \\
\hline 9 & Effort to include all available studies, including contact with authors & 11 \\
\hline 10 & Databases and registries searched & 11 \\
\hline 11 & Search software used, name and version, including special features used (eg, explosion) & 11 \\
\hline 12 & Use of hand searching (eg, reference lists of obtained articles) & 11 , fig 1 \\
\hline 13 & List of citations located and those excluded, including justification & 11, fig 1 \\
\hline 14 & Method of addressing articles published in languages other than English & 11 \\
\hline 15 & Method of handling abstracts and unpublished studies & 11 \\
\hline 16 & Description of any contact with authors & 11 \\
\hline \multicolumn{3}{|c|}{ Reporting of methods should include } \\
\hline 17 & $\begin{array}{l}\text { Description of relevance or appropriateness of studies assembled for assessing the } \\
\text { hypothesis to be tested }\end{array}$ & 11 \\
\hline 18 & $\begin{array}{l}\text { Rationale for the selection and coding of data (eg, sound clinical principles or } \\
\text { convenience) }\end{array}$ & 11 \\
\hline 19 & $\begin{array}{c}\text { Documentation of how data were classified and coded (eg, multiple raters, blinding } \\
\text { and interrater reliability) }\end{array}$ & 11 \\
\hline 20 & $\begin{array}{c}\text { Assessment of confounding (eg, comparability of cases and controls in studies where } \\
\text { appropriate) }\end{array}$ & 11 \\
\hline 21 & $\begin{array}{l}\text { Assessment of study quality, including blinding of quality assessors, stratification or } \\
\text { regression on possible predictors of study results }\end{array}$ & 11 \\
\hline 22 & Assessment of heterogeneity & 7,8 , fig 5 \\
\hline 23 & $\begin{array}{l}\text { Description of statistical methods (eg, complete description of fixed or random effects } \\
\text { models, justification of whether the chosen models account for predictors of study } \\
\text { results, dose-response models, or cumulative meta-analysis) in sufficient detail to be } \\
\text { replicated }\end{array}$ & 11 \\
\hline 24 & Provision of appropriate tables and graphics & Fig 1 \\
\hline \multicolumn{3}{|c|}{ Reporting of results should include } \\
\hline 25 & Graphic summarizing individual study estimates and overall estimate & Tables 1,2 \\
\hline 26 & Table giving descriptive information for each study included & Tables 1,2 \\
\hline 27 & Results of sensitivity testing (eg, subgroup analysis) & $\begin{array}{l}2,6-8, \text { Fig } \\
2-3-4\end{array}$ \\
\hline 28 & Indication of statistical uncertainty of findings & 7,8, Fig. 5 \\
\hline 29 & Quantitative assessment of bias (eg, publication bias) & 7,8 , fig 5 \\
\hline 30 & Justification for exclusion (eg, exclusion of non-English language citations) & Fig 1, 11 \\
\hline 31 & Assessment of quality of included studies & 11 \\
\hline \multicolumn{3}{|c|}{ Reporting of conclusions should include } \\
\hline 32 & Consideration of alternative explanations for observed results & 8,9 \\
\hline 33 & $\begin{array}{l}\text { Generalization of the conclusions (ie, appropriate for the data presented and within the } \\
\text { domain of the literature review) }\end{array}$ & 11 \\
\hline 34 & Guidelines for future research & $8,9,11$ \\
\hline 35 & Disclosure of funding source & 12 \\
\hline
\end{tabular}




\subsection{Data extraction and quality assessment}

A protocol was defined prior to the search including the population criteria, description of oncologic treatments, comparisons, and outcomes of interest. A systematic Literature search was performed using the PubMed (MEDLINE), EMBASE and The Cochrane Library. The search was performed comprehensively using several databases from each one's earliest start until 1 ${ }^{\text {st }}$ August 2019. We sought to identify all English language researches evaluating the effect of GAS use on outcome of patients receiving concomitant oral chemotherapy or TKIs for solid tumors. For the process of evidence acquisition, Literature was queried using the following terms [MeSH]: "gastric acid suppressant" OR "proton pump inhibitors", and "chemotherapy" or "tyrosine kinase inhibitors" AND "carcinoma" or "cancer" AND "survival". References of included studies were hand-searched in order to identify potentially relevant adjunctive papers. For each study we extracted the following information, if available: number of patients, baseline patients' characteristics, data regarding oncologic treatments, progression-free (PFS) or recurrence-free (RFS) survivals and overall survival (OS) or the corresponding HRs, and overall response rates (ORRs) in the 2 arms.

Two independent reviewers (AI and FP) evaluated all studies in order to verify the inclusion criteria. Studies selection was conducted with a two-phase screening. First level screening excluded titles and abstracts meeting the following criteria: a) case reports, letters, comments, and reviews not reporting original data; b) in vivo and/or in vitro studies; c) studies involving fewer than 10 patients; and d) language publication other than English. Studies matching inclusion criteria were obtained in the complete form and reviewed in full-text version for an advanced assessment. Second level full-text screening was performed in order to include studies with the following criteria: (1) studies involving patients with solid tumors receiving oral chemotherapy or TKIs; (2) studies reporting outcomes of patients receiving concomitant GAS therapy compared to those who did not; (3) information regarding HRs or survival curves for OS and/or PFS and/or ORRs for patients using GAS compared to those who did not. Differences of opinion were resolved by agreement between the reviewers. Study quality was independently evaluated using the Newcastle-Ottawa Quality Assessment scale for case-control studies [42]. Disagreement was also resolved by consultation and consensus.

\subsection{Statistical analysis}

The primary outcome of interest was OS. The secondary endpoints were PFS and ORR. The HRs and 95\% CIs from each study were either extracted directly from original papers or calculated using Kaplan-Meier curves based on the method of Tierney et al [43]. Random effects models with inverse variance weighting were calculated using Review Manager (RevMan 5.3, The Nordic Cochrane Center, Copenhagen, Denmark). The heterogeneity of the underlying population was assessed using the Q-statistic and $\mathrm{I}^{2}$ test. For the interpretation, $\mathrm{I}^{2}$ values greater than $50 \%$ were considered to be heterogeneous [44]. Publication bias was assessed by visually evaluating a funnel plot (Begg's and Egger's test, Fig. 4).

\section{Conclusions}

The use of GAS during cancer therapy with capecitabine or TKIs should be offered with caution because it may result in a reduction of anticancer treatment and finally may significantly affect therapeutic outcomes. In our meta-analysis, we observed a significantly worse OS and PFS in patients receiving GAS during cancer treatment with anti-EGFR TKIs or capecitabine-based regimens in GI cancers and NSCLC. In conclusion, except for clear clinical reasons (concomitant use of steroids/non-steroidal anti-inflammatory drugs, severe gastroesophageal reflux disease/gastritis/peptic ulcer) GAS should be avoided during treatment with oral anticancer drugs for solid tumors.

Author Contributions: Conceptualization, A.I., M.G. and F.P.; Methodology, F.P..; Software, F.P.; Validation, F.P.; Formal Analysis, F.P.; Investigation, F.P.; Resources, M.G and F.G.; Data Curation, F.P.; Writing - Original 
Draft Preparation, A.I., M.G., F.P. and A.F.; Writing - Review \& Editing, G.T., F.G. and E.R.; Visualization, F.P and A.I.; Supervision, F.G and A.F..; Project Administration, F.P.; Funding Acquisition, F.G.".

Funding: This research received no external funding.

\section{Acknowledgments: -}

Conflicts of Interest: The authors declare no conflict of interest.

\section{References}

1. Kaye, S.B. New antimetabolites in cancer chemotherapy and their clinical impact. Br J Cancer 1998, 78 Suppl 3, 1-7, doi:10.1038/bjc.1998.747.

2. Marty, M.; Extra, J.M.; Espie, M.; Leandri, S.; Besenval, M.; Krikorian, A. Advances in vinca-alkaloids: Navelbine. Nouv Rev Fr Hematol 1989, 31, 77-84.

3. O'Reilly, S.M.; Newlands, E.S.; Glaser, M.G.; Brampton, M.; Rice-Edwards, J.M.; Illingworth, R.D.; Richards, P.G.; Kennard, C.; Colquhoun, I.R.; Lewis, P., et al. Temozolomide: a new oral cytotoxic chemotherapeutic agent with promising activity against primary brain tumours. Eur J Cancer 1993, 29A, 940-942, doi:10.1016/s0959-8049(05)80198-4.

4. Hutson, T.E.; Lesovoy, V.; Al-Shukri, S.; Stus, V.P.; Lipatov, O.N.; Bair, A.H.; Rosbrook, B.; Chen, C.; Kim, S.; Vogelzang, N.J. Axitinib versus sorafenib as first-line therapy in patients with metastatic renal-cell carcinoma: a randomised open-label phase 3 trial. Lancet Oncol 2013, 14, 1287-1294, doi:10.1016/S1470-2045(13)70465-0.

5. Maemondo, M.; Inoue, A.; Kobayashi, K.; Sugawara, S.; Oizumi, S.; Isobe, H.; Gemma, A.; Harada, M.; Yoshizawa, H.; Kinoshita, I., et al. Gefitinib or chemotherapy for non-small-cell lung cancer with mutated EGFR. N Engl J Med 2010, 362, 2380-2388, doi:10.1056/NEJMoa0909530.

6. Motzer, R.J.; Hutson, T.E.; Tomczak, P.; Michaelson, M.D.; Bukowski, R.M.; Rixe, O.; Oudard, S.; Negrier, S.; Szczylik, C.; Kim, S.T., et al. Sunitinib versus interferon alfa in metastatic renal-cell carcinoma. $N$ Engl J Med 2007, 356, 115-124, doi:10.1056/NEJMoa065044.

7. Rosell, R.; Carcereny, E.; Gervais, R.; Vergnenegre, A.; Massuti, B.; Felip, E.; Palmero, R.; Garcia-Gomez, R.; Pallares, C.; Sanchez, J.M., et al. Erlotinib versus standard chemotherapy as first-line treatment for European patients with advanced EGFR mutation-positive non-small-cell lung cancer (EURTAC): a multicentre, open-label, randomised phase 3 trial. Lancet Oncol 2012, 13, 239-246, doi:10.1016/S1470-2045(11)70393-X.

8. Sternberg, C.N.; Davis, I.D.; Mardiak, J.; Szczylik, C.; Lee, E.; Wagstaff, J.; Barrios, C.H.; Salman, P.; Gladkov, O.A.; Kavina, A., et al. Pazopanib in locally advanced or metastatic renal cell carcinoma: results of a randomized phase III trial. J Clin Oncol 2010, 28, 1061-1068, doi:10.1200/JCO.2009.23.9764.

9. van der Graaf, W.T.; Blay, J.Y.; Chawla, S.P.; Kim, D.W.; Bui-Nguyen, B.; Casali, P.G.; Schoffski, P.; Aglietta, M.; Staddon, A.P.; Beppu, Y., et al. Pazopanib for metastatic soft-tissue sarcoma (PALETTE): a randomised, double-blind, placebo-controlled phase 3 trial. Lancet 2012, 379, 1879-1886, doi:10.1016/S0140-6736(12)60651-5.

10. Savarino, V.; Dulbecco, P.; de Bortoli, N.; Ottonello, A.; Savarino, E. The appropriate use of proton pump inhibitors (PPIs): Need for a reappraisal. Eur J Intern Med 2017, 37, 19-24, doi:10.1016/j.ejim.2016.10.007.

11. Ohgami, M.; Kaburagi, T.; Kurosawa, A.; Doki, K.; Shiozawa, T.; Hizawa, N.; Homma, M. Effects of Proton Pump Inhibitor Coadministration on the Plasma Concentration of Erlotinib in Patients With Non-Small Cell Lung Cancer. Ther Drug Monit 2018, 40, 699-704, doi:10.1097/FTD.0000000000000552. 
12. Vishwanathan, K.; Dickinson, P.A.; Bui, K.; Cassier, P.A.; Greystoke, A.; Lisbon, E.; Moreno, V.; So, K.; Thomas, K.; Weilert, D., et al. The Effect of Food or Omeprazole on the Pharmacokinetics of Osimertinib in Patients With Non-Small-Cell Lung Cancer and in Healthy Volunteers. J Clin Pharmacol 2018, 58, 474-484, doi:10.1002/jcph.1035.

13. Budha, N.R.; Frymoyer, A.; Smelick, G.S.; Jin, J.Y.; Yago, M.R.; Dresser, M.J.; Holden, S.N.; Benet, L.Z.; Ware, J.A. Drug absorption interactions between oral targeted anticancer agents and PPIs: is pH-dependent solubility the Achilles heel of targeted therapy? Clin Pharmacol Ther 2012, 92, 203-213, doi:10.1038/clpt.2012.73.

14. Suttle, A.B.; Ball, H.A.; Molimard, M.; Hutson, T.E.; Carpenter, C.; Rajagopalan, D.; Lin, Y.; Swann, S.; Amado, R.; Pandite, L. Relationships between pazopanib exposure and clinical safety and efficacy in patients with advanced renal cell carcinoma. Br J Cancer 2014, 111, 1909-1916, doi:10.1038/bjc.2014.503.

15. Verheijen, R.B.; Swart, L.E.; Beijnen, J.H.; Schellens, J.H.M.; Huitema, A.D.R.; Steeghs, N. Exposure-survival analyses of pazopanib in renal cell carcinoma and soft tissue sarcoma patients: opportunities for dose optimization. Cancer Chemother Pharmacol 2017, 80, 1171-1178, doi:10.1007/s00280-017-3463-x.

16. Lalani, A.A.; McKay, R.R.; Lin, X.; Simantov, R.; Kaymakcalan, M.D.; Choueiri, T.K. Proton Pump Inhibitors and Survival Outcomes in Patients With Metastatic Renal Cell Carcinoma. Clin Genitourin Cancer 2017, 15, 724-732, doi:10.1016/j.clgc.2017.05.019.

17. Mir, O.; Touati, N.; Lia, M.; Litiere, S.; Le Cesne, A.; Sleijfer, S.; Blay, J.Y.; Leahy, M.; Young, R.; Mathijssen, R.H.J., et al. Impact of Concomitant Administration of Gastric Acid-Suppressive Agents and Pazopanib on Outcomes in Soft-Tissue Sarcoma Patients Treated within the EORTC 62043/62072 Trials. Clin Cancer Res 2019, 25, 1479-1485, doi:10.1158/1078-0432.CCR-18-2748.

18. Chen, Y.M.; Lai, C.H.; Chang, H.C.; Chao, T.Y.; Tseng, C.C.; Fang, W.F.; Wang, C.C.; Chung, Y.H.; Wang, Y.H.; Su, M.C., et al. Antacid Use and De Novo Brain Metastases in Patients with Epidermal Growth Factor Receptor-Mutant Non-Small Cell Lung Cancer Who Were Treated Using First-Line First-Generation Epidermal Growth Factor Receptor Tyrosine Kinase Inhibitors. PLoS One 2016, 11, e0149722, doi:10.1371/journal.pone.0149722.

19. Chu, M.P.; Ghosh, S.; Chambers, C.R.; Basappa, N.; Butts, C.A.; Chu, Q.; Fenton, D.; Joy, A.A.; Sangha, R.; Smylie, M., et al. Gastric Acid suppression is associated with decreased erlotinib efficacy in non-small-cell lung cancer. Clin Lung Cancer 2015, 16, 33-39, doi:10.1016/j.cllc.2014.07.005.

20. Chu, M.P.; Hecht, J.R.; Slamon, D.; Wainberg, Z.A.; Bang, Y.J.; Hoff, P.M.; Sobrero, A.; Qin, S.; Afenjar, K.; Houe, V., et al. Association of Proton Pump Inhibitors and Capecitabine Efficacy in Advanced Gastroesophageal Cancer: Secondary Analysis of the TRIO-013/LOGiC Randomized Clinical Trial. JAMA Oncol 2017, 3, 767-773, doi:10.1001/jamaoncol.2016.3358.

21. Fang, Y.H.; Yang, Y.H.; Hsieh, M.J.; Hung, M.S.; Lin, Y.C. Concurrent proton-pump inhibitors increase risk of death for lung cancer patients receiving 1st-line gefitinib treatment - a nationwide population-based study. Cancer Manag Res 2019, 11, 8539-8546, doi:10.2147/CMAR.S222278.

22. Graham, C.; Orr, C.; Bricks, C.S.; Hopman, W.M.; Hammad, N.; Ramjeesingh, R. A retrospective analysis of the role of proton pump inhibitors in colorectal cancer disease survival. Curr Oncol 2016, 23, e583-e588, doi:10.3747/co.23.3204.

23. Ha, V.H.; Ngo, M.; Chu, M.P.; Ghosh, S.; Sawyer, M.B.; Chambers, C.R. Does gastric acid suppression affect sunitinib efficacy in patients with advanced or metastatic renal cell cancer? J Oncol Pharm Pract 2015, 21, 194-200, doi:10.1177/1078155214527145. 
24. Kumarakulasinghe, N.B.; Syn, N.; Soon, Y.Y.; Asmat, A.; Zheng, H.; Loy, E.Y.; Pang, B.; Soo, R.A. EGFR kinase inhibitors and gastric acid suppressants in EGFR-mutant NSCLC: a retrospective database analysis of potential drug interaction. Oncotarget 2016, 7, 85542-85550, doi:10.18632/oncotarget.13458.

25. McAlister, R.K.; Aston, J.; Pollack, M.; Du, L.; Koyama, T.; Chism, D.D. Effect of Concomitant $\mathrm{pH}$-Elevating Medications with Pazopanib on Progression-Free Survival and Overall Survival in Patients with Metastatic Renal Cell Carcinoma. Oncologist 2018, 23, 686-692, doi:10.1634/theoncologist.2017-0578.

26. Sharma, M.; Holmes, H.M.; Mehta, H.B.; Chen, H.; Aparasu, R.R.; Shih, Y.T.; Giordano, S.H.; Johnson, M.L. The concomitant use of tyrosine kinase inhibitors and proton pump inhibitors: Prevalence, predictors, and impact on survival and discontinuation of therapy in older adults with cancer. Cancer 2019, 125, 1155-1162, doi:10.1002/cncr.31917.

27. Sun, J.; Ilich, A.I.; Kim, C.A.; Chu, M.P.; Wong, G.G.; Ghosh, S.; Danilak, M.; Mulder, K.E.; Spratlin, J.L.; Chambers, C.R., et al. Concomitant Administration of Proton Pump Inhibitors and Capecitabine is Associated With Increased Recurrence Risk in Early Stage Colorectal Cancer Patients. Clin Colorectal Cancer 2016, 15, 257-263, doi:10.1016/j.clcc.2015.12.008.

28. Tvingsholm, S.A.; Dehlendorff, C.; Osterlind, K.; Friis, S.; Jaattela, M. Proton pump inhibitor use and cancer mortality. Int J Cancer 2018, 143, 1315-1326, doi:10.1002/ijc.31529.

29. Wong, G.G.; Ha, V.; Chu, M.P.; Dersch-Mills, D.; Ghosh, S.; Chambers, C.R.; Sawyer, M.B. Effects of Proton Pump Inhibitors on FOLFOX and CapeOx Regimens in Colorectal Cancer. Clin Colorectal Cancer 2019, 18, 72-79, doi:10.1016/j.clcc.2018.11.001.

30. Zenke, Y.; Yoh, K.; Matsumoto, S.; Umemura, S.; Niho, S.; Ohmatsu, H.; Goto, K.; Ohe, Y. Clinical Impact of Gastric Acid-Suppressing Medication Use on the Efficacy of Erlotinib and Gefitinib in Patients With Advanced Non-Small-Cell Lung Cancer Harboring EGFR Mutations. Clin Lung Cancer 2016, 17, 412-418, doi:10.1016/j.cllc.2016.01.006.

31. Zhang, J.L.; Liu, M.; Yang, Q.; Lin, S.Y.; Shan, H.B.; Wang, H.Y.; Xu, G.L. Effects of omeprazole in improving concurrent chemoradiotherapy efficacy in rectal cancer. World J Gastroenterol 2017, 23, 2575-2584, doi:10.3748/wjg.v23.i14.2575.

32. Targownik, L.E.; Metge, C.; Roos, L.; Leung, S. The prevalence of and the clinical and demographic characteristics associated with high-intensity proton pump inhibitor use. Am J Gastroenterol 2007, 102, 942-950, doi:10.1111/j.1572-0241.2007.01106.x.

33. Corleto, V.D.; Festa, S.; Di Giulio, E.; Annibale, B. Proton pump inhibitor therapy and potential long-term harm. Curr Opin Endocrinol Diabetes Obes 2014, 21, 3-8, doi:10.1097/MED.0000000000000031.

34. Egorin, M.J.; Shah, D.D.; Christner, S.M.; Yerk, M.A.; Komazec, K.A.; Appleman, L.R.; Redner, R.L.; Miller, B.M.; Beumer, J.H. Effect of a proton pump inhibitor on the pharmacokinetics of imatinib. Br J Clin Pharmacol 2009, 68, 370-374, doi:10.1111/j.1365-2125.2009.03466.x.

35. Hilton, J.F.; Tu, D.; Seymour, L.; Shepherd, F.A.; Bradbury, P.A. An evaluation of the possible interaction of gastric acid suppressing medication and the EGFR tyrosine kinase inhibitor erlotinib. Lung Cancer 2013, 82, 136-142, doi:10.1016/j.lungcan.2013.06.008.

36. van Leeuwen, R.W.; Peric, R.; Hussaarts, K.G.; Kienhuis, E.; NS, I.J.; de Bruijn, P.; van der Leest, C.; Codrington, H.; Kloover, J.S.; van der Holt, B., et al. Influence of the Acidic Beverage Cola on the Absorption of Erlotinib in Patients With Non-Small-Cell Lung Cancer. J Clin Oncol 2016, 34, 1309-1314, doi:10.1200/JCO.2015.65.2560. 
37. Xu, Z.Y.; Li, J.L. Comparative review of drug-drug interactions with epidermal growth factor receptor tyrosine kinase inhibitors for the treatment of non-small-cell lung cancer. Onco Targets Ther 2019, 12, 5467-5484, doi:10.2147/OTT.S194870.

38. Cho, S.; Yee, J.; Kim, J.Y.; Jeong Rhie, S.; Gwak, H.S. Effects of Concomitant Medication Use on Gefitinib-Induced Hepatotoxicity. J Clin Pharmacol 2018, 58, 263-268, doi:10.1002/jcph.1010.

39. Togashi, Y.; Masago, K.; Masuda, S.; Mizuno, T.; Fukudo, M.; Ikemi, Y.; Sakamori, Y.; Nagai, H.; Kim, Y.H.; Katsura, T., et al. Cerebrospinal fluid concentration of gefitinib and erlotinib in patients with non-small cell lung cancer. Cancer Chemother Pharmacol 2012, 70, 399-405, doi:10.1007/s00280-012-1929-4.

40. Deng, Y.; Feng, W.; Wu, J.; Chen, Z.; Tang, Y.; Zhang, H.; Liang, J.; Xian, H.; Zhang, S. The concentration of erlotinib in the cerebrospinal fluid of patients with brain metastasis from non-small-cell lung cancer. Mol Clin Oncol 2014, 2, 116-120, doi:10.3892/mco.2013.190.

41. Stroup, D.F.; Berlin, J.A.; Morton, S.C.; Olkin, I.; Williamson, G.D.; Rennie, D.; Moher, D.; Becker, B.J.; Sipe, T.A.; Thacker, S.B. Meta-analysis of observational studies in epidemiology: a proposal for reporting. Meta-analysis Of Observational Studies in Epidemiology (MOOSE) group. JAMA 2000, 283, 2008-2012, doi:10.1001/jama.283.15.2008.

42. Wells, G.; Shea, B.; O'Connell, D. The Newcastle-Ottawa Scale (NOS) for assessing the quality of nonrandomized studies in meta-analyses. 2015.

43. Parmar, M.K.; Torri, V.; Stewart, L. Extracting summary statistics to perform meta-analyses of the published literature for survival endpoints. Stat Med 1998, 17, 2815-2834, doi:10.1002/(sici)1097-0258(19981230)17:24<2815::aid-sim110>3.0.co;2-8.

44. Higgins, J.P.; Thompson, S.G. Quantifying heterogeneity in a meta-analysis. Stat Med 2002, 21, 1539-1558, doi:10.1002/sim.1186. 